\title{
Constitutional Justice of Russia within the judicial landscape of contemporary Europe ${ }^{* *}$
}

\section{La justicia constitucional de Rusia en el escenario judicial europeo contemporáneo}

ABSTRACT

The Russian Federation became a member of the Council of Europe in 1996. This step determined the development of Russia's judicial system for the coming several decades and made it possible for Russia's national system of law to integrate into judicial landscape of Europe, thereby enabling Russia to uphold democratic values. The emergence of new legislation affected all branches of Russia's system of law. But the experience of the two decades has demonstrated that such modernization can be effective only by way of dialogue rather than by simple copying and implementing international rules.

An important role in this process was played by the Constitutional Court of the Russian Federation (RF) that was founded in 1991. The paper reviews the role it played in the 1993 Constitutional crisis, examines the Court's structure and powers, and also analyzes the juridical nature of its decisions. The Author analyzes the collisions between decisions handed down by the European Court of Human Rights and the Constitution of Russia from the point of view of the stand taken by the Constitutional Court of the RF. In the end, the Author arrives at the conclusion that there is a need for a dialogue among European and national systems of justice with the help of filtration mechanisms and multilevel constitutionalism.

Ph.D. in History from UssR Academy of Sciences. Master's degree in Law and Historian from the Lomonosov Moscow State University. Deputy Head of State Policies Chair from Lomonosov Moscow State University, Russia. Contact: abramova-m@mail.ru

Recibido el 27 de mayo de 2017, aprobado el 15 de octubre de 2017.

Para citar el artículo: ABRAmova, M. Constitutional Justice of Russia within the judicial landscape of contemporary Europe. Derecho del Estado n. ${ }^{\circ} 40$, Universidad Externado de Colombia, enero-junio de 2018, pp. 21-44. DOI: HTTPS://DOI.ORG/10.18601/01229893.N40.02 
KEYWORDS

Constitutional Court of the Russian Federation, decisions, European Court of Human Rights (ECHR), European Conventional Law, democratic values, human rights, collisions, implementation, filtration, multilevel constitutionalism.

\section{RESUMEN}

La Federación Rusa se convirtió en miembro del Consejo de Europa en 1996. Este proceso determinó el desarrollo del sistema judicial ruso y permitió que el sistema legal nacional pudiese integrarse al escenario judicial europeo, permitiendo incluso que Rusia tuviese valores democráticos. La aparición de esta nueva legislación afectó todas las ramas del sistema legal ruso; sin embargo, el transcurso de más de dos décadas demuestra que tal avance solo puede hacerse efectivo en la medida que exista un verdadero diálogo judicial más allá de la réplica e implementación de normas internacionales.

Es por esto que la Corte Constitucional de la Federación Rusa, establecida en 1991, ha jugado un rol determinante. Este artículo revisa el rol que desempeñó esta corporación durante la crisis constitucional de 1993, examina su estructura, sus poderes y la naturaleza jurídica de sus decisiones. Analiza además las colisiones entre las decisiones del Tribunal Europeo de Derechos Humanos y la Constitución rusa (desde la perspectiva adoptada por la Corte Constitucional rusa). Finalmente concluye que existe la necesidad de establecer un verdadero diálogo entre los sistemas de justicia europeo y nacional, con la ayuda de mecanismos de filtración y constitucionalismo multinivel.

PALABRAS CLAVE

Corte Constitucional rusa, decisiones judiciales, Corte Europea de Derechos Humanos, derecho convencional europeo, valores democráticos, derechos humanos, colisiones, implementación, filtración, constitucionalismo multinivel.

\section{CONTENTS}

Introduction. 1. The establishment of constitutional justice in Russia. 2. Structure and powers of the Constitutional Court of the Russian Federation. 3. Juridical nature of decisions handed down by Russia's Constitutional Court. 4. Collisions between decisions of the European Court on Human Rights (ECHR) and the Constitution of Russia from the point of view of the Constitutional Court of Russian Federation. Conclusions. References. 
INTRODUCTION

The disintegration of the USSR and the construction of new statehood in Russia in the 1990s placed an important task before the country, namely - to work out and adopt new legislation that complied with the conditions whereby the country was going over to a market economy and democratic regime. It was precisely in this way that the Russian Federation could strive to enter the European legal landscape and build its relations with other States on a parity basis. However, in the process of forming a new system of law Russia encountered a number of problems of a legal nature, as well as of a socioeconomic and political character.

Russia ascended to the Charter of the Council of Europe on February 28, 1996. As it ascended the Charter, the Russian Federation signed the European Convention on Human Rights and Fundamental Freedoms (hereinafter - Convention), the Convention against Torture, Cruel Other Inhuman and Degrading Treatment or Punishment, the Framework Convention on the Protection of National Minorities and the European Charter on Local Self-Government.

The Conventions were ratified two years later in 1998. The two year period that was required for upgrading domestic legislation on application of laws to comply with Conventions and standards of the Council of Europe, was a very short period, if one takes into account the amount of work that had to be done. ${ }^{1}$

It was precisely due to the haste with which the Conventions were ratified in Russia is the reason, as we see it, many discrepancies and shortcomings concerning their application, objective difficulties of Russia's transition from the Soviet regime to a democracy were not taken into account. Besides that, there were also contradictions of a much deeper significance. These difficulties stem from the fact that Russia belongs to the Continental (Romano-Germanic) system of written law in which the main source of law is the normative legal act. The Convention and court practice based on its normative guidelines are a vivid example of precedent-based law that belongs to the Anglo-American system of law. The norm-parameters in the Convention are filled with legal content via a precedent-interpretation which is simply not used in Russia's internal legal regulation practice, and moreover, it is not recognized by Russia's juridical doctrine in general.

Consequently, by ratifying the Convention, Russia acquired for herself, at the end of the 1990's, an uncharacteristic supranational "addition" or "second-helping" to its system of law. Also, one must take into account the growing number of precedents themselves, (at the moment, there are more than 15,000$)$, as well as the peculiar mechanism of updating the norm-

1 Many countries needed for this process much more time, and the record is France by signing the European Convention in 1950, it ratified it only in 1974. 
guidelines via the practically annual appearance of new additional Protocols to the Convention. Therefore, it is possible to say that there has appeared in Russia's legal system quite a strange or alien (both from the materialistic and procedural points of view) organism that is constantly growing, and having a tendency to squeeze out national legal institutions, norms and traditions.

Certain countries (the Netherlands, Austria) give priority to the Convention over and above their own Constitutions; in a considerable number of countries (France, Spain and others) the Convention has a higher status than ordinary laws, but lower than their Constitutions; in other countries (Great Britain, Russia) it has the status of common law. And, this is no coincidence, since neither Great Britain nor Russia have their sights set on acquiring membership of West European "State within a State" (European Union).

Until recently, it seemed that on the issue of relationship between Russia's Constitution and the Convention there was absolutely no serious theoretical problem. After all, both the Constitution and the Convention quite clearly "refer to a coinciding catalogue of fundamental rights and freedoms," 2 and in 2006, Russia's Constitutional Court pointed out in its Resolution that the subject of its regulation, as well as that of the ECHR, was one and the same, namely - human rights and fundamental freedoms.

However, every year is witnessing a growing number of ECHR rulings that artificially precipitated collisions between statutes in Russia's Constitution and in the Convention. As a result, the ECHR is factually demanding chat Russia must change its Constitution - a demand that is unconditionally groundless from the legal point of view.

Certain Russian jurists and politicians have proposed, and are still proposing, the easiest way of resolving such collisions - to quit the 1950 Convention - and the most radical of them, even propose to quit the Council of Europe.

However, in our opinion such a solution to the problem of collisions does not at all look constructive in the present-day world of a global movement of Sts and their systems of law. After the Convention was ratified, Russia adopted a great number of legislative acts upholding civil rights that allow Russia to integrate into the European legal landscape. By their ongoing dialogue and mutual interest, the ECHR and the Constitutional Court of Russia are enriching and improving each other's practice, and in so doing, are uniting national and supranational efforts to ensure contemporary law and order, and that is was structuring of the European Convention into Russia's system of law corresponds with the legal development of Russia strategically.

However, it is important to remember: any demands from the outside to alter or change the National Constitution are unacceptable. That is why the

2 Zorkin, V. D. The dialogue of the Constitutional Court of the Russian Federation and the European Court on Human Rights in the context of constitutional order. Viewed 27 May 2017. Available from: ksrf.ru>News/Speech/Pages/ViewItem.aspx 
only possible choice for us is: to embark upon an honest road of building such a system of law and order which, on the one hand, would cover the adopted (by Russia also) international legal standards concerning human rights, and on the other hand, this process will be carried out not by way of their implementation of mechanically carrying them over to the national system of law. Such interlinking and mutual enrichment of national and supranational legal regulation practice in the $21^{\text {st }}$ Century should be conducted by way of dialogue mechanisms, cultures and traditions. ${ }^{3}$

The blending or combining of national systems of law, as one of the main contemporary integration tendencies should be based on a thorough study of national legal practice, on the law-administering traditions and on the specific understanding of jurisprudence by the population of a given State.

\section{THE ESTABLISHMENT OF CONSTITUTIONAL JUSTICE IN RUSSIA}

A study of the relationship between national and supranational regulation would not be complete and objective without defining the role and the place of the Constitutional Court of the Russian Federation in the system of law of present-day Russia. The Constitutional Court occupies a special place within the system of bodies of empowered with State authority on Russia since it acts as an arbiter between the State, on the one hand, and its citizens on the other hand. Its decisions and judgments define the constitutionality of adopted decisions and exert great influence on politics. It also acts as the guarantor of the existing Constitution, and in so doing, it safeguards the constitutionality of politics.

The Constitutional Court was established in Russia in 1991. This was but one of the landmark events confirming new Russia's firm adherence to European legal values. This was the first time in the entire history of Russia that such a new body of judicial power had been created in its State system.

However, that body had a predecessor - it was the USSR Constitutional Oversight (Supervision) Committee that was created during the perestroika (or restructuring) period in 1989. However, since the USSR did not have a system in which authority was shared, the functions of that Committee were insignificant. Unlike that Committee, the Constitutional Court was vested with broad authority - and this enabled it to participate actively and constructively in regulating the 1992-1993 constitutional crisis in Russia. ${ }^{4}$

3 See Acosta Alvarado, P. A. Diálogo judicial y constitucionalismo multinivel. El caso de la red judicial latinoamericana. Bogotá: Universidad Externado de Colombia, 2014; AcosTA Alvarado, P. A. El diálogo judicial interamericano, un camino de doble vía hacia la protección efectiva. Diálogo entre cortes. Arcaro Conci, L. y Mezzetti, L. (eds.). Brasilia: oAB, 2015.

4 See Vitruk, N. V. Constitutional Justice in Russia (1991-2001). Notes on Theory and Practice. Moscow: Gorodets-Izdat, 2001. 
In order to occupy such a post in the political system of Russia, the Constitutional Court, and especially its Chairman, Valeri Zorkin, had to cover a long and difficult road. ${ }^{5}$ The tragic pages in the contemporary history of Russia are related to the beginning of the 1990s - more precisely, with the rule of the first President of Russia - Boris Yeltsin. His Decree on September 21, 1993 "On the stage-by-stage reform in the Russian Federation," abolished the old parliament - the Supreme Soviet and designated elections of the president and a new parliament - the State Duma. What is more, Yeltsin "proposed" not to convene a session of the Constitutional Court of the Russian Federation so as not to give an official evaluation of the President's actions.

And this is precisely when the Chairman of the Constitutional Court, Valeri Zorkin, and other Court Judges took a heroic stand: the Constitutional Court did not agree with that (Yeltsin's) "proposal." The Constitutional Court handed down its Conclusion that classified the Decree and (Yeltsin's) September 21, 1993 "Appeal of the President to the citizens of Russia" as not complying with the Constitution of the Russian Federation and serving as grounds for removal (impeachment) of the President from office. On September 22, 1993, Yeltsin issued a new Decree No. 1400 on dissolving Parliament which laid the groundwork for the Constitutional Court to hand down a ruling that immediately declared Boris Yeltsin's presidential powers null and void.

How the events at the end of September and the beginning of October unfolded (in Moscow) are well-known and have become part of Russia's history: an armed conflict broke out between the Supreme Soviet Deputies (parliament members) and President Yeltsin. The majority of the parliament members refused to obey Yeltsin's Decree, and the Presidium of the Supreme Soviet (top ruling body of the Parliament) passed a ruling that his (Yeltsin's) presidential powers were terminated the moment he had signed the above-mentioned Decree.

On October 7, 1993 Yeltsin signed a new Decree which established that the legal regulation of issues of a budgetary-financial nature, questions concerning land reform, property, civil service and social activity of the population were to be implemented by the President of the Russian Federation. ${ }^{6}$ The question which comes to mind here is the following: why should such serious and quite complicated questions which, by far, did not always require urgent decision, should be regulated by (presidential) Decrees, rather than by (parliamentary) laws? The Parliament was practically stripped of its legislative functions and the country was slipping towards emergency legislation. Actually, what Yeltsin was doing was concentrating all the ruling powers in the State into his own hands, and terminating the activity of many governing bodies in the center and at local levels. ${ }^{7}$

5 See Zorkin, V. D. Contemporary World, Law and the Constitution. Moscow: Norma, 2010.

6 Colton, T. Yeltsin. Moscow: Colibry, 2013, 45.

7 Fyodorov, B. G. Ten Mad Days with Boris Yeltsin. Moscow: Algorithm, 2011, 137.

Revista Derecho del Estado n. ${ }^{\circ}$ 40, enero-junio de 2018, pp. 21-44 
An open conflict or showdown between Yeltsin and the Constitutional Court was unfolding. In his October 7, 1993 Decree, Yeltsin asserted that the Constitutional Court "...had transformed from a body of constitutional justice into a weapon of political struggle that posed an exclusive threat to the State." However, according to the Law of that period of time, the Constitutional Court had the power and authority to give its own assessment of the acts of (legislative) bodies and of top officials in the State. Nonetheless, a threat of elimination was looming over the Constitutional Court. Yeltsin's (October 7) Decree contained the idea of abolishing the Constitutional Court, and replacing it with a Collegium (Panel) of the Supreme Court having similar functions. However, that idea did not come in for support in Yeltsin's entourage, and the Constitutional Court was preserved. True, its powers and authority were substantially "clipped."

For example, the Constitutional Court was no longer empowered to hand down an assessment of the constitutional acts and actions of top level officials. The Constitutional Court no longer had the right to assess the constitutionality of political parties and other public associations. ${ }^{8}$ The Draft Law (or Bill) on the Constitutional Court had assumed leaving the Court the right to assess the constitutionality of practical cases of applying judicial powers. However, another approach concerning this issue got the upper hand, and it is reflected in the text of the Law: the Constitutional Court shall assess the constitutionality of the applied law or the law to be applied in respect to a given case, upon complaints of violation of the Constitutional rights and freedoms of a citizen, and in respect to court requests.

The Constitutional Court held its ground in a very serious - and not just a constitutional, but social-political crisis which, by its intensity, was akin to a small civil war.

\section{STRUCTURE AND POWERS OF THE CONSTITUTIONAL COURT OF THE RUSSIAN FEDERATION}

Constitutional justice, as a type of judicial action, is an inseparable part or feature of a law-governed State. The activity and structure of Russia's Constitutional Court are regulated by the Constitution of the $\mathrm{RF}^{9}$ and the Federal Constitutional Law. ${ }^{10}$

8 Chairman of Russia's Constitutional Court Valeriy Zorkin denounces Yeltsin's crimes. Viewed 27 May 2017. Available from: http://www.prezidentpress.ru/news/zakon/1622-glavaks-rf-valeriy-zorkin-protiv-prestupleniy-elcina.html

9 Constitution of the Russian Federation - 1993. Art. 125. Viewed 29 May 2016. Available from: http://base.garant.ru/10103000/7/\#block_7000

10 Federal Constitutional Law as of July 21, 1994, No. 1-FCL "On Constitutional Court of Russian Federation”. Viewed 29 May 2016. Available from: http.//base.garant.ru/10101207/ 
The Constitutional Court is empowered with the following authority: its main goal is to exercise constitutional supervision, i.e., to consider cases on the correspondence to the Constitution of the Russian Federation of normative acts and treaties, to resolve disputes concerning the competence between federal bodies of State power, between federal bodies and bodies of State power in the subjects of the Russian Federation; to assess the constitutionality of the applied law or the law to be applied in respect to a given case, upon complaints of violation of the Constitutional rights and freedoms of a citizen, and in respect to court requests; to interpret the Constitution of Russia; at the request of the Federation Council, ${ }^{11}$ to submit its conclusion on observance of the established order for tabling accusations of State treason or having committed some other grave crime against the President; to set forth the legislative initiative on questions and issues within its jurisdiction.

Since the Constitutional Court has the right to interpret the Constitution and Federal Laws, this enhances the efficiency of its work in strengthening statehood based on law and upgrading the unified field of jurisdiction.

Legal Acts or the individual statutes thereof that have been found unconstitutional are declared null and void, while international treaties that do not correspond with the Constitution of the Russian Federation shall not be introduced or applied in Russia.

Therefore, it may be said that the specific role of the Constitutional Court as a body of constitutional supervision in Russia enables it to act as the arbiter in disputes concerning interpretation of laws. In so doing, it (Constitutional Court) clears the legal field from improperly passed statutes, thereby compelling legislators to take a more responsible approach to law-making.

The Constitutional Court of Russia consists of nineteen judges. The Judges are appointed by the Federation Council upon presentation by the President, by secret ballot voting. The Constitutional Court is empowered to conduct its functions upon the presence of two-thirds of the overall number of its judges. The powers of the Court are not limited to any particular period of time. The candidates for the post of a judge in this Court must meet more stringent requirements than for posts in other courts: at least 40 years of age, 15 years of judicial practice and acknowledged scientific reputation. The age limit for holding such a post in the Constitutional Court is 70 years. The Court is based in St. Petersburg.

Up to 2011, the Court consisted of two Chambers. Such a structure ensured the maximum possible number of judicial cases to pass through the Court in the conditions that existed during that period. This was in line with the traditional understanding of the continuity principle, whereby the Court

11 Federal Council is one of the chambers of the Federal Assembly (Russian Parliament). 
was not able to examine a new legal case without having completed the preceding one.

However, a new principle that rescinded this restriction was adopted by the Russian Constitutional judiciary system in 2011. This system introduced a long-standing and widely-used in many European States procedure of resolving Constitutional judicial cases without holding hearings, and that is why division of the Court was no longer needed. ${ }^{12}$

The main vector of the Russian Constitutional Court's work is examining complaints concerning alleged violations of Constitutional rights and freedoms of citizens. Annually, the Court receives from 14,000 to 19,000 complaints from citizens, which testifies to the people's trust of the Constitutional Court.

\section{JURIDICAL NATURE OF DECISIONS HANDED DOWN BY RUSSIA'S CONSTITUTIONAL COURT}

The stand of the Russian Constitutional Court on different issues is expressed in the decisions it hands down. Summaries on these decisions are compiled on an annual basis. For instance, the 2009 Summary presented information concerning fulfillment of the Constitutional Court's decisions; in 2012 - information on what had been done to improve the Court's work in protecting citizens' rights and freedoms; in 2014 - the Court's work to upgrade the judiciary system. The Court also regularly (quarterly and semi-annually) issues Reviews of the Court's activity. These documents are posted on the Constitutional Court's official Internet-Portal and serve Russian courts as guidelines in their work. ${ }^{13}$

Decisions of the Constitutional Court are formulated as Acts and Conclusions. ${ }^{14}$ An Act is the name given to a decision taken on issues concerning the constitutionality of the normative legality of an Act (Bill) or on an international treaty (agreement) that has not yet come into force, as well as on disputes concerning the competence and on interpretations of the RF Constitution; while the Court's conclusions deal with observance of a prescribed procedure for charging the President of the Russian Federation of committing a grave offense..$^{15}$

12 Federal Constitutional Law as of July 21, 1994, No. 1-FCL "On Constitutional Court of Russian Federation". Art. 47. Viewed 29 May 2016. Available from: http.//base.garant. $\mathrm{ru} / 10101207 /$

13 See Official website of Russia's Constitutional Court. Available from: http://www.ksrf. $\mathrm{ru} / \mathrm{ru} / \mathrm{info}$

14 Federal Constitutional Law as of July 21, 1994, No. 1-FCL "On Constitutional Court of Russian Federation”. Art. 71. Viewed 27 May 2017. Available from: http.//base.garant. $\mathrm{ru} / 10101207 /$

15 Constitutional Court has not issued its conclusions since the Russian Constitution came into force in 1993. 
The Court is also empowered to hand down its Qualification - most often this concerns defining its motivation of a decision on refusal to accept a citizen's complaint.

The overwhelming majority of the Court's decisions on constitutionally motivated complaints of citizens (or their organizations) - complaints related to practically the entire spectrum of political, economic, labor, social and other relations. A total of 270,664 complaints were filed in the Constitutional Court from January 1, 1995 to September 2013, on which the Court handed down 368 Acts and 15,386 Qualifications.

If we speak about the content aspect of the Constitutional Court's activity, we should note, first of all, that its decisions concern the widest range of issues related to Constitutional status of the individual, free economic entrepreneurship, sovereign integrity of Russian statehood, organization of public authority, federative structure, local self-government, juridical responsibility, various types of judiciary. By no means would it be an exaggeration to say that actual comprehensive perception of Russian law-making would have been impossible without taking into account the legal groundwork established by the Constitutional Court. This is now recognized as being quite natural for a present-day law-governed democracy, since it recognizes that man, his rights and freedoms, are the uppermost constitutional value.

Neither does the Constitutional Court sidestep principles of constitutional significance of different branches of law, thereby promoting them to a kind of "constitutionalization". For instance, in decisions of the Russian Constitutional Court you will come across direct mention of Civil Legislation principles (Decision No. 20-P) as of December 23, 2003; constitutional principles of regulating economic relations (Decision No. 10-P) as of June 22, 2009; basic principles of legally regulating relations in the sphere of the natural environment and ecological safety (Decision No. 8-P) as of May 14, 2009; the principle concerning the need to uphold the rights and legitimate interests of the employee as the least protected party in labor relationships (Decision No. 3-P) as of March 15, 2005. Moreover, the Court does not limit itself to a simple reminder of these principles in its decisions, but also lays the legal groundwork of its demands addressed to courts. For example, then and again the Constitutional Court has drawn attention to the fact that implementation of the principle about all being equal before the law and in court would be impossible without observing its inherent criteria of common sense, proportionality, as well as the need to limit rights and freedoms in a democratic law-governed society: what is more, public interests ${ }^{16}$ may justify legal limitations of rights and freedoms - only if such limitations adequately conform with the socially required result; the goal of only rationally orga-

16 Constitution of the Russian Federation - 1993. Art. 55 [Viewed 25 May 2016]. Available from: http://base.garant.ru/10103000/7/\#block_7000 
nizing the work of bodies of power cannot serve as the basis for limiting rights and freedoms; any differentiation that leads to variations of the rights and duties of legal entities is impermissible - only if such a differentiation is objectively justified, well-founded and pursues constitutionally significant objectives, and that the legal means employed for attaining such goals are comparable to them (Acts of the CC of the RF No. 15-P as of October 30, 2003, No. 7-P as of June 16, 2006, No. 14-P as of June 22, 2010, No. 20-P as of October 10, 2013 and others).

At the same time, it should be noted that the Constitutional Court acts not only as "a negative lawmaker" whose decisions boil down to "disqualifying" laws or their normative statutes..$^{17}$ On the contrary, more often than not, in cases when there is a departure from the norms of the Constitution due to interpretation of an applied law, the Constitutional Court refrains from passing a verdict of unconstitutional norm. By acting in this manner, the Court actually admits that such a law arbitrarily is in line with the Constitution, and this therefore obliges all (parties) to follow this particular interpretation, and consequently, any departure from it will be tantamount to violation of the Constitution. Making use of such possibilities enables the Constitutional Court to avoid creating legislative loopholes and not to intrude (even in temporary legal settlements) in the Parliament's legislative work.

In the opinion of Court Chairman Valeri Zorkin, the practical work of the Constitutional Court has demonstrated a tendency to avoid recognition of disputed norms as being "unconstitutional" if there is a possibility of defining its constitutional-legal sense and its proper content that excludes any other interpretation in the practice of applying laws. ${ }^{18}$

In 2015, the Constitutional Court handed down 34 Acts and 3,111 Qualifications. ${ }^{19}$ Seventeen of the 34 Acts concerned changing of Federal Laws, and one Act dealt with changing legislation of a legal entity of the Russian Federation.

When speaking about the Acts, it should be noted that the normative principles are to be found both in the resolution and motivation portions. The resolution portions formulate the norms that either confirm, or on the contrary, negate the constitutionality of the norms in question, or they formulate the normative principles that are to explain or define specific constitutional norms. In such cases when the Constitutional Court is compelled to terminate this or that unconstitutional norm, it then formulates a new, but temporary norm.

17 Volkova, N. S. and Habrieva, T. Y. Legal Principles of Constitutional Court of RF and Parliament. Moscow: Norma, 2005, 26.

18 Zorkin, V. D. Constitutional Development of Russia. Moscow: Norma, 2011, 183.

19 See Official website of Russia's Constitutional Court. Available from: http://www.ksrf. $\mathrm{ru} / \mathrm{ru} / \mathrm{info}$ 
The legal principles in the motivation portion of the Court's Decisions are not always formulated as norms - quite often they acquire forms of "prescriptive" or "suggestive" units.

Summarizing Decisions of the Constitutional Court are quite often linked with interpretation of the Constitution of the RF. Such an interpretation may be special if it is given upon requests of the President, the Federation Council, the State Duma, the Government, legislatures of legal entities (or subjects) of the RF, or they may be casual (incidental) - in all other cases, they are resolved in court. In 2015, the Constitutional Court handed down its interpretation of two Articles of the Constitution of the RF.

The juridical power of the Constitutional Court's qualification Decisions supersedes the juridical power of any Law, and consequently, it is practically equal to the juridical power of the Constitution itself. The question of whether to consider a Decision made by the Court a source of law or not remains open for discussion in the corridors of Russian jurisprudence. Some of the experts in this field view Constitutional Court Decisions as sources of Law while others disagree. Such eminent Russian jurists as S.S. Alexeyev, M.N. Marchneko, B.A. Strashun, T.V. Solovyova and M. V. Baglai base their view of the Court's Decisions as sources of Law on various positions. ${ }^{20} \mathrm{At}$ the same time, Academician V. S. Nersesyantz holds that it is impossible to view courts as a law-making source. ${ }^{21}$

Today, Russian jurisprudence is experiencing an ever more popular viewpoint that Constitutional Court law-making is a special, diversified form of modern law-making undertaken by the uppermost bodies of judicial power in order to create optimal conditions for administrating justice. ${ }^{22}$

During the past 25 years of its activity, the Constitutional Court has formulate the legal principles in all spheres of legal regulation, thereby determining the constitutionality of laws and bylaws. Moreover, here we are talking about current regulation activity, as well as about parameters whereby the State functions, ensuring implementation of the principles of democracy, divisions of authority and State sovereignty. During this period, gross, and the most obvious violations of the Constitution have disappeared

20 Alekseyev, S. S. The State and Law. Moscow: Prospekt, 2017; Baglai, M. V. A Lawgoverned State: From ideas to practice. Kommunist, 1989, 6; MARCHENKo, M. N. Juridical nature and character of the European Court of Human Right's (ECHR) decisions. Moscow State University Vestnik (Law), 2016, 2, 3-20; Solovyova, T. A. Acts issues by Supreme Court of RF, Constitutional Court of RF and European Court of Human Rights in the sphere of civil law and the procedure of their implementation. Moscow: Monograph. O. V. IsaYenkova (ed.). 2011; Strashun, B. A. Decisions of RF Constitutional Court as a source of law. Moscow: Norma, 2000.

21 NeRSESYANTZ, V. S. The court does not make laws, neither does it govern - It applies laws. Judicial practice as a source of law. Moscow, 1997.

22 Maliushin, A. A. Forms of performing law-making function of the Constitutional legislation and their place in the hierarchy of the sources of the Russian Law. Law Problems. $2015,10,59-64$. 
from Russia's system of law. Such violations today are to be found only at the level of interpretation and in systemic links of norms. Therefore, it may be said that virtual unconstitutionality has become rarer in Russian legislation.

COMPARATIVE TABLE

OF NORMATIVE STATUTES RECOGNIZED

BY THE CONSTITUTIONAL COURT AS CORRESPONDING

(NOT CORRESPONDING) TO THE CONSTITUTION

OF THE RUSSIAN FEDERATION (2010-2015) ${ }^{23}$

\begin{tabular}{|c|c|c|c|c|}
\hline YEAR & $\begin{array}{c}\text { Total } \\
\text { Numbers } \\
\text { OF AdOPTED } \\
\text { DeCISIONS }\end{array}$ & $\begin{array}{c}\text { Resolutions ReCognizing } \\
\text { Normative Statue as } \\
\text { CorResponding to THE } \\
\text { CONSTITUTION OF THE } \\
\text { RusSian FEDERATION }\end{array}$ & $\begin{array}{c}\text { Resolutions Recognizing } \\
\text { Normative Statue as } \\
\text { Not Corresponding to } \\
\text { the Constitution of the } \\
\text { Russian Federation }\end{array}$ & $\begin{array}{c}\text { INSTRUCTIONS } \\
\text { ON THE NEED } \\
\text { FOR NEW LEGAL } \\
\text { REGULATION }\end{array}$ \\
\hline 2010 & 22 & 17 & 7 & 7 \\
\hline 2011 & 30 & 18 & 15 & 12 \\
\hline 2012 & 34 & 23 & 18 & 18 \\
\hline 2013 & 30 & 15 & 26 & 18 \\
\hline 2014 & 33 & 41 & 20 & 16 \\
\hline 2015 & 34 & 18 & 19 & 14 \\
\hline
\end{tabular}

In the first decades after the Constitution was adopted, the socio-political rift and inter-ethnic conflicts represented the greatest danger to Russia since they were fraught with collapse of the State. All other threats such as mounting poverty, the merging of authority and big business, corruption could be overcome, but collapse of the State would be tantamount to disappearance of the country. Not only did the State have to preserve itself, it had to be able to effectively uphold the rights of its citizens. It was precisely from such considerations that the Constitutional Court proceeded in the 1990's as it sought to find a lawful compromise, and made historic decisions for the country on the so-called Case of the CPSU (Communist Party of the Soviet Union), as well as on restoring Constitutional Law in the Chechen Republic, and on declaration of a moratorium on the death sentence.

However today, beginning as of 2008 , in conditions of the financial-andeconomic crisis, the Court has been consistently taking measures to uphold

23 Informative and Analytical Report on fulfillment of Russia's Constitutional Court decisions adopted during implementation of Constitutional Jurisprudence in 2015. Viewed 27 May 2017. Available from: http://www.ksrf.ru/ru/Info/Maintenance/Informationks/Pages/ ReportKS2015.аsрхм 
the social rights of citizens, thereby instilling the State to reform social legislation in that direction. All this, taken together, fosters social-political stability which is extremely important for the country.

In the period from 2012 to 20015, the Court received 45,700 queries out of which, more than 12,100 concerned upholding the Constitutional rights and freedoms of citizens (including 1,100 protecting labor rights; over 2,300 protecting housing rights; some 3,800 upholding social rights); more than 1,200 queries concerning protection of the Constitutional right (on organizing public authority; more than 8,800 queries concerning civil rights and procedures; more than 18,100 queries dealing with criminal law and court procedures. $^{24}$

Moreover, the content of these queries testifies to the desire and striving of the citizens of Russia to attain lawful equality: equality to life and housing, equality before the law and in court, equality for oneself and for one's children in having access to education, healthcare and cultural values. However, when such strivings come up against insurmountable obstacles in the form of these or those social, political and economic institutions, the principle of equal rights undergoes deformation, creating a gap between law and rights. Taking into account the special emphasis made by citizens in their queries concerning social injustices, one should be especially aware of the very dangerous property-ownership stratification of citizens that came about as a result of organizing privatization of State-owned properties in the 1990's.

Here are two quite simple examples pertaining to the current work of the Constitutional Court. The first example concerns Constitutional Court Decision No. 26, dating October 30, 2014. It deals with the enquiry made by the Parliament of the Chechen Republic to the Constitutional Court on the matter of the constitutionality of the amendments to the Law on Civil Service. These amendments were introduced in 2013 and they concerned new requirements for contenders to the post of a civil servant - namely, such a contender had to serve a tour of duty in the Army before taking up a post as a civil servant. Here, I would like to explain that prior to 2014 young men in the Republic of Chechnya were not called up to serve in the Army since that republic was rebuilding itself after the armed actions in the 1990s. So, it turned out that without having served a tour of duty in the Army, such young men were unable to contend for a post as civil servant, and this was the reason for submitting a complaint to the Constitutional Court. The Constitutional Court handed down a ruling abolishing the requirement concerning Army service because it violated the principles of justice (fairness), equity

24 Zorkin, V. D. Constitutional Justice in transitional stage of historical development of Russia. Viewed 25 May 2017. Available from: http://www.ksrf.ru/ru/News/Speech/Pages/ ViewItem .aspx ?ParamId=75 
and commensurability, as well as the right to choose a field of activity and profession by taking a civil service job.

The second example concerns Constitutional Court Decision No. 13 dating, dating April 12, 2014 which deals with increasing the sum of the fine for breaking a traffic rule if this offense was committed in two subjects of Russia - cities of Federal significance, i.e., Moscow and St. Petersburg. The Constitutional Court found these principles not running counter to the Constitution since they were based on objective criteria and took into account the complicated and more publicly dangerous road-and-traffic situation in these two major cities of Russia.

The work of the Constitutional Court of the RF testifies to the correctness of the choice to make it the supreme arbiter in settling Constitutional legal disputes, as well as the official interpreter and "guardian" of Russia's Constitution..$^{25}$

\section{COLLISIONS BETWEEN DECISIONS OF THE EUROPEAN COURT ON HUMAN RIGHTS (ECHR) AND THE CONSTITUTION OF RUSSIA FROM THE POINT OF VIEW OF THE CONSTITUTIONAL COURT OF RUSSIAN FEDERATION}

The question concerning the legal nature of the Constitutional Court's Acts is especially interesting. What concerns decisions in which the Court determines the validity of this or that law of the Constitution, then such judgments are not normative acts since they do not create new norms. THE Constitution itself is one such act, whereas decisions of the Constitutional Court are acts defining their application. There have been cases described in juridical literature when such Constitutional Court decisions have been ranked higher than acts of parliament and decrees of the President. However, this is not true - either such decisions proclaim this or that law unconstitutional, or it simply means that the Constitution which, by its juridical nature, stands higher than acts of parliament and decrees of the President, as well as of other State bodies.

Neither does the Constitutional Court create new legal norms in the process of interpreting the Constitution. Interpretation must not be confused either with some specific norm of law, or with the norms of law, in general. Interpretation is always only a rule for properly understanding the already existing norms of law - it is not a new norm.

Several rulings of Russia's Constitutional Court contain references to the European Convention. What is more, in a number of cases it refers to the practice of the European Court of Human Rights, thereby entering Russian practice of applying law into the European context.

25 Ostapovich, I. Y. Constitutional Court of RF in normative forming process. Russian Juridical Journal, 2010, 133-138. 
Following are several examples of such mutual exchange: for instance, on November 20, 2007, the Constitutional Court of Russia adopted Ruling No. 13-P on the Statutes of the Criminal Procedural Code of the R. F. (hereinafter - CPC), The given Ruling does not allow individuals (to whom compulsory medical measures based on conclusions of psychiatrists have been taken) to personally participate in the criminal proceedings and court sessions, to become acquainted with the materials of the case, or to file appeals or complaints in respect to adopted decisions. The Constitutional Court of the Russian Federation found these statutes of the CPC as not complying with the Constitution - since according to their meaning acquired in the course of law administering practice - they do not allow citizens to implement their court procedural rights. In essence, this decision of Russia's Constitutional Court can be viewed as fulfillment of the ruling of the European Court on Human Rights as of October 20, 2005 on the case of "Romanov versus Russia." It was precisely this document that pointed out that the presence of the applicant in the courtroom was a necessary condition allowing the judge to become convinced of the psychic condition of the applicant and to adopt a fair conclusion. In this manner, the Constitutional Court of the Russian Federation while examining the issue about the constitutionality of a number of BPC norms simultaneously resolved the question of bringing into line with European standards.

In the opinion of N. Bondar, a Judge of Russia's Constitutional Court, "while assessing the influence of the decisions of the European Court of Human Rights on the practice of the Constitutional Court's forms of controlling norms of law - abstract or specific - the following should be noted: out of 168 decisions and rulings of Russia's Constitutional Court, as of May 1,2010 , refer directly to judicial principles of the ECHR, or refer to its decisions; 160 decisions were adopted under direct norm control procedures; four more decisions were passed under abstract and another four by "joint norm control" procedures. ${ }^{26}$ A number of the Constitutional Court's decisions refer to conventional norms in the interpretation of the ECHR and were used not only for founding the legal basis of the Court's stand on the given case, but were also included in the resolution part of its decision. Russia's Constitutional Court is more and more often referring to the ECHR's practice within the framework of constitutionally interpreting the norms of current legislation in order to consolidate its stand in a given case. For instance, such an approach helps to more clearly understand the normative content of this or that institution of law, its main (universal) parameters, ${ }^{27}$ the juridical

26 Available from: URL: http://pravo.ru/story/view/112919/ Viewed 25 May 2017.

27 The decision of the Constitutional Court of the Russian Federation dated 14.07.2005, No.9-P, concerning constitutionality of article 113 of the Tax Code of the Russian Federation in 
nature of certain constitutional rights, the limits of permissible restrictions of constitutional rights and so on.

In this manner, the Constitutional Court of Russia is integrating with ECHR decisions and its interpretation of the constitutionality of disputed legal judgments and the legal stand of the ECHR. It is apparent that all this has a noticeable impact on the practice of constitutional justice, and at the same time, precisely because of this, the decisions and judgments of Russia's Constitutional Court acquire intra-State formal juridical significance.

At the same time, we must not forget that ECHR's decisions are of a complex juridical nature. It is necessary to differentiate the juridical consequences of ECHR decisions as acts of exercising rights and juridical consequences as acts of interpreting the European Convention for the Protection of Human Tights that contains a normative element. As acts of exercising rights, i.e., juridical facts resulting in consequences for the disputing parties, ECHR decisions are to be implemented according to Article 46 of the Convention. As acts of interpretation, it is generally acknowledged that the ECHR"s establishment of one or several violations, the Convention obligates that State to put an end to such violations and to rectify the consequences, and as far as it is possible, to restore the situation that existed prior to the violation.

The main problem that the Constitutional Court of Russia has encountered in its work is the following: simultaneously, it must resolve two not-so-easily compatible tasks, namely, to harmonize Russia's legal system (system of law) with Europe's general legal landscape, on the one hand, and to uphold its own Constitutional identity, on the other hand.

The aspects of this problem concern both its content and procedure since Russia ranks first among the Member-States of the Council of Europe in terms of the absolute number of complaints filed in the ECHR.

The given problem became aggravated in 2009-2010 upon taking up the case of "Konstantin Markin versus Russia" that precipitated the issue of specifying the role of the Constitutional Court within the mechanism of implementing Conventions. The essence of "the "Markin Case" can be described as follows: are there or are there not signs of discrimination in a situation when a male serviceman is denied a three-year maternity leave to take care of a newborn child as female servicewomen are entitled to?

In this matter, there is an obvious under-estimation of Russia's socio-cultural specifics, and when the ECHR demanded that it (Russia) had to overcome what the ECHR called "gender-biased traditions that had become a widespread opinion among the inhabitants of a given country." And indeed, one must admit that such gender prejudices have, by far, not been overcome in Russia. And, indeed, herein lays the rub! Such prejudices are to be found NOT in the 
legal system of the country, but rather in the reality of family relationships that are still based, to a considerable degree, on patriarchal traditions of distributing roles among men and women. It is precisely because of this that Russian legislators endeavor, where it is possible, to grant women legislative preferences which, by their legal essence, are not privileges, but rather lawful compensation for those additional efforts in bringing up children that fall on the shoulders of woman in Russian families.

Such legislative preferences for women can, in no way, be viewed as measures of discrimination against males, but rather should be regarded as a way of overcoming discrimination against women that still can be found in our society.

Here, I feel there is a need to underscore the following: in principle, Russia's stand on this issue is not, in any way, at variance with general European values concerning gender equality (including in the matter of distributing responsibilities among men and women in bringing up children). Different views on this issue arise only when it comes to choosing the means ensuring such equality while taking into consideration the specific historical peculiarities of the timeframe and locality where the given value is being implemented.

While examining the Constitutional Court's attitude to ECHR Decisions, and fulfillment of its own Decisions, here, it is necessary to point out that the Constitutional Court steadfastly upholds the principle of obligatory implementation of ECHR Decisions in the territory of Russia. This point has been emphasized time and again, in particular, in Act 21-Pas of July 14, 2015, and in Act 12-P as of April 19, 2016. When examining its cases, the Constitutional Court analyzes the practical work of the ECHR on corresponding cases, and when necessary, it may introduce legal principles and clauses of the ECR directly into the text of its own Decisions.

And indeed, one must admit that Russian law has acquired European features to a considerable degree. Today, we cannot "close our eyes" to or "side-step" such "collisions" between Russia's Constitutional system and decisions handed down by European supra-national structures: this is because it has become so deeply involved in the European legal landscape.

It should be noted that out of 168 decisions adopted by Russia's Constitutional Court, as of May 1, 2010, refer directly to judicial principles of the ECHR, or refer to its decisions; 160 decisions were adopted under direct norm control procedures; four more decisions were passed under abstract and another four by "joint norm control" procedures. A number of the Constitutional Court's decisions refer to conventional norms in the interpretation of the ECHR and were used not only for founding the legal basis of the Court's stand on the given case, but were also included in the resolution part of its decision. Russia's Constitutional Court is more and more often referring to the ECHR's practice within the framework of constitutionally interpreting the norms of current legislation in order to consolidate its stand in a given case. 
For instance, such an approach helps to more clearly understand the normative content of this or that institution of law, its main (universal) parameters, the juridical nature of certain constitutional rights, the limits of permissible restrictions of constitutional rights and so on.

In this manner, the Constitutional Court of Russia is integrating with ECHR decisions and its interpretation of the constitutionality of disputed legal judgments and the legal stand of the ECHR. It is apparent that all this has a noticeable impact on the practice of constitutional justice, and at the same time, precisely because of this, the decisions and judgments of Russia's Constitutional Court acquire intra-State formal juridical significance.

At the same time, we must not forget that ECHR's decisions are of a complex juridical nature. It is necessary to differentiate the juridical consequences of ECHR decisions as acts of exercising rights and juridical consequences as acts of interpreting the European Convention for the Protection of Human Tights that contains a normative element. As acts of exercising rights, i.e., juridical facts resulting in consequences for the disputing parties, ECHR decisions are to be implemented according to Article 46 of the Convention. As acts of interpretation, it is generally acknowledged that the ECHR"s establishment of one or several violations, the Convention obligates that State to put an end to such violations and to rectify the consequences, and as far as it is possible, to restore the situation that existed prior to the violation.

On June 11,2015, a group of 93 State Duma members ${ }^{28}$ file a query in the RF Constitutional Court concerning "contradictions" between national and supranational statutes concerning law and order. Certain mass media outlets lost no time in linking the query of State Duma members to the Constitutional Court with the ECHR's decision in the "YukOs Oil Company versus Russia" Case, ${ }^{29}$ ruling that Russia had to pay out two billion Euros as compensation. ${ }^{30}$

However, in their query, the State Duma Deputies focused their main attention on another ECHR decision concerning the complaint of "Anchugov and Gladkov v. Russia" ${ }^{31}$ wherein the ECHR upheld the Statute of the Russian Constitution which annuls the right to vote for convicts who have violated the European Convention on protecting human rights and fundamental freedoms. The given case concerning the right to vote for convicts was put forth

28 State Duma is the second chamber of the Federal Assembly (Russian Parliament).

29 OAo Neftyanaya Kompaniya Yukos v. Russia. Application N 14902/04, Judgment of 24 June 2014. Viewed 24 May 2017. Available from: http://www.garant.ru/products/ipo/prime/ doc/70059678/

30 Kalinichenko, P. A. On the question of collision between ECHR Acts and Russian Constitutional Acts from the point of view of principles of the RF Constitutional Court. Timely Problems of Russian Law, 2016, 2, 42-48.

31 Anchugov and Gladkov v. Russia. Applications N 11157/04 and 15162/05, of 4 July 2013. Viewed 22 May 2017. Available from: http://base.garant.ru/70639826/ 
by two Russian citizens, each of whom were serving prison sentences for murder and several other crimes.

In its time, Russia's Constitutional Court rejected such a complaint on the grounds that the process of checking whether certain principles of Russian Constitution correspond with other principles of Russia's Fundamental Law is not within the competence of the Constitutional Court. However, the European Court to which the convicts referred their complaint found, that in the given case, there had indeed been a violation of the right to participate in an election that is guaranteed by Article 3 in Protocol 1 to the Convention on protecting human rights and fundamental freedoms. ${ }^{32}$

However, the ECHR failed to take into account that the convicts who filed their complaint had disputed not simply the norm of the law, but the norm of Russia's Constitution. And what is more, this concerns a norm that can be altered or amended ONLY by adopting a new Constitution. On this account, the ECHR, in its decision, noted only that the plaintiff-State (Russia) would be able to observe the Convention "by somehow changing the form of the political process or its interpretation of Russia's Constitution."

In plain English, this meant that Russia should either adopt a new Constitution within a framework corresponding to "a new form of political process," or give a very flexible interpretation of its text. But agreement with stand taken by the ECHR and granting the convicts the right to vote in elections would have been a direct violation of the Russian Constitution principles in terms of their highest juridical power, as well as the priority above any other acts of law.

In this situation, the Constitutional Court, on July 14, 2015, passed an Act that found the disputed legal principles as "not contradicting the Constitution of the Russian Federation."

In its Act passed on April 19, 2016, the Court ruled that legal actions of an individual nature were not applicable in respect to citizen Anchugov (convicted of murder, theft and fraud) and citizen Gladkov (convicted of murder, robbery and participation in organized crime), who were sentenced to death and subsequently were commuted to 15 years in prison. These two men were convicted of committing especially grave crimes, and consequently this means that they should have realized beforehand that they were not eligible to make use of the active electoral right either according to the Constitution of the RF or any international standards.

In its work, the Constitutional Court proceeds from the fact that Russia's participation in international agreements does, not at all, imply that it gives up its national sovereignty. No international treaty, including the European Convention on the Protection of Human Rights ad Fundamental Freedoms, 
and the stand of the ECHR based on the aforementioned document, can nullify the priority of the Russian Constitution. However, the practical implementation of the documents and principles mentioned above in the Russian legal system is possible only on condition of recognizing the Constitution as having the supreme and uppermost juridical power of Russia's Constitution and the European Convention on Protection o of Human Rights and Fundamental Freedoms are based on one and the same values. Collisions between the two are extremely rare. Nonetheless, such cases are possible, and then, Russia shall refrain from fulfilling ECHR decisions. In fact, such procedure is in line with the practice other countries, and should proceed from the idea of not allowing self-isolation, mutual respect and promoting dialogues among different systems for protecting human rights.

Here, it is necessary to point out that only the Constitutional Court is empowered to hand down a decision rejecting fulfillment of ECHR decisions. Without such a stipulation, there remains a threat of "washing out" the country's constitutional supervision in the matter of Russian legislation corresponding with the laws of the Council of Europe..$^{33}$ The need for a rational combination of national laws and international conventions was emphasized by the Chairman of Israel's Supreme Court, Miriam Naor, addressing the VI International Forum of Jurists in May of 2016. In particular, the speaker declared: "Human Rights Pacts have been adopted not for the purpose of helping mankind to commit suicide." ${ }^{4}$

\section{CONCLUSIONS}

Once again, the Constitutional Court has underscored its recognition of the fundamental significance of the European system for protecting the human rights of man and citizen, a part of which are ECHR decisions, and has also expressed its readiness to seek a legitimate compromise for supporting and upholding this system. Confirmation of the high degree of such integration steps can be seen in the dynamics of making use of ECHR decisions in the Acts passed by the Russian Constitutional Court over the past several fiveyear periods: in the 2000-2004 period $-15.9 \%$ of the Constitutional Court's decisions contained references to ECHR decisions; in 2005-2009 - such references already numbered $39.1 \%$, and in the $2010-2014$ period - this number stood at $41.2 \% .^{35}$

33 Zorkin, V. D. Problems of implementing Human Rights Convention. Viewed 20 May 2017. Available from: http://www.ksrf.ru/ru/News/Speech/Pages/ViewItem.aspx?ParamId=72

34 Official Website of Russia's Constitutional Court. Viewed 24 May 2017. Available from: http://www.ksrf.ru/ru/News/Speech/Pages/ViewItem.aspx?ParamId=76

35 Bondar, S. N. Value-based origins of legal implementation of Convention requirements for Russia's legal system. Journal of Constitutional Justice, 2016, 2 (50), 8. 
At this point, it should be noted that the degree of mutual integration is a factor that the Constitutional Court leaves within its own realm to decide since the borderlines of a compromise on the given issue are determined precisely by Russia's Constitution. And this factor fits in precisely with the already existing practice of mutual interaction between the ECHR and a whole number of Member-States that have signed the said Convention.

The European continent today is experiencing a mutual integration process involving varying legal norms. And, the main elements or spheres of this process are European institutions on international public law, on the one hand, and national institutions of constitutional law, on the other hand. And here, it is necessary to bear in mind that in the present-day conditions, these two elements, or spheres, international public law and constitutional law are regulating relations that in many respects quite similar in nature, and coincide to a considerable extent to the areas that they cover.$^{36} \mathrm{On}$ this basis, it seems there is a possibility to witness the emergence of a qualitatively new transnational phenomenon of law that implies the crystallization of European constitutionalism. This is a qualitatively new world philosophical-viewpoint category that is reflected not so much in the supranational legal universalization, as in the national-constitutional integration of State-legal systems of Europe on the basis of reciprocal enrichment, while still preserving the juridical sovereignty of the legal systems. Here, we are talking about filtration of convention norms in the national systems of law.

Colombian expert of Constitutional Law P.A. Acosta Alvarado wrote about the growing role of judges in the reformulation process of correlation between international and national law. ${ }^{37}$ This seems to bring forth a kind of "polypnonia" of present-day European constitutionalism, or, as the eminent Bulgarian Constitutionalist, Yevgeniy Tanchev, remarked: it is a manifestation of "multilevel constitutionalism" in the European continent. ${ }^{38}$ And this is based on the premise that mutual interaction between European and national legal systems is unfeasible in conditions of subordination, and that only a dialogue between the corresponding legal systems can guarantee general European legal development.

36 Konyukhova, I. A. Tendencies, problems and prospects of harmonizing Constitutional Law and International Public Law in conditions of present-day development. Constitutional Law and International Law in contemporary times. Moscow: RAP, 2010, 14-40.

37 Acosta Alvarado, P. A. Más allá de la utopía: del diálogo interjudicial a la constitucionalización del derecho internacional. La red judicial latinoamericana como prueba y motor del constitucionalismo multinivel. Tesis de doctorado, Madrid, 2015, 217. Viewed 25 May 2017. Available from: http://eprints.ucm.es/28119/1/T35645.pdf

38 TANCHEV, T. Constitutional pluralism and multilevel governance in the European Union. Journal of Foreign Legislation and Comparative Law Studies, 2014, 6 (49), 1052-1062. 


\section{REFERENCES}

Acosta Alvarado, P. A. (2015). El diálogo judicial interamericano, un camino de doble vía hacia la protección efectiva. Diálogo entre cortes. LuIz ArCaro Conci y LuCA Mezzetti (eds.). Brasilia: oAb.

Acosta Alvarado, P. A. (2014). Diálogo judicial y constitucionalismo multinivel. El caso de la red judicial latinoamericana. Bogotá: Universidad Externado de Colombia.

Alekseyev, S. S. (2017). The State and Law. Moscow: Prospekt.

Baglai, M. V. (1989). A Law-governed State: From ideas to practice. Kommunist. 6, 20-29.

Bondar, S. N. (2016). Value-based origins of legal implementation of Convention requirements for Russia's legal system. Journal of Constitutional Justice. 2 (50), 4-10.

Colton, T. (2013). Yeltsin. Moscow: Colibry.

Fyodorov, B. G. (2011). Ten Mad Days with Boris Yeltsin. Moscow: Algorithm.

Kalinichenko, P. A. (2016). On the question of collision between echr Acts and Russian Constitutional Acts from the point of view of principles of the RF Constitutional Court. Timely Problems of Russian Law. 2, 42-48.

Konyukhova, I. A. (2010). Tendencies, problems and prospects of harmonizing Constitutional Law and International Public Law in conditions of present-day development. Constitutional Law and International Law in contemporary times. Moscow: RAP.

Maliushin, A. A. (2015). Forms of performing law-making function of the constitutional legislation and their place in the hierarchy of the sources of the Russian Law. Law Problems, 10, 59-64.

Marchenko, M. N. (2016). Juridical nature and character of the of the European Court on Human Right's (ECHR) decisions. Moscow State University Vestnik (Law), 2, 3-20.

NERSESYANTZ, V. S. (1997). The court does not make laws, neither does it govern - It applies laws. Judicial practice as a source of law. Moscow.

Ostapovich, I. Y. (2010). Constitutional Court of RF in normative forming process. Russian Juridical Journal. 133-138.

Solovyova, T. A. (2011). Acts issues by Supreme Court of RF, Constitutional Court of RF and European Court on Human Rights in the sphere of civil law and the procedure of their implementation. O. V. Isayenkova (ed.). Moscow: Monograph.

Strashun, B. A. (2000). Decisions of RF Constitutional Court as a source of law. Moscow: Norma.

TAnchev, T. (2014). Constitutional pluralism and multilevel governance in the European Union. Journal of Foreign Legislation and Comparative Law Studies. 6 (49), 1052-1062.

Vitruk, N. V. (2001). Constitutional Justice in Russia (1991-2001). Notes on Theory and Practice. Moscow: Gorodets-Izdat. 
Volkova, N. S. and Habrieva, T. Y. (2005). Legal Principles of Constitutional Court of $R F$ and Parliament. Moscow: Norma.

Zorkin, V. D. (2011). Constitutional Development of Russia. Moscow: Norma.

Zorkin, V. D. (2010). Contemporary World, Law and the Constitution. Moscow: Norma.

\section{Literature from Web Site}

Acosta Alvarado, P. A. (2015). Más allá de la utopía: del diálogo interjudicial a la constitucionalización del derecho internacional. La red judicial latinoamericana como prueba y motor del constitucionalismo multinivel. Tesis de doctorado. Madrid. Available from: http://eprints.ucm.es/28119/1/T35645.pdf

Anchugov and Gladkov v. Russia. (2013). Applications n. 11157/04 and 15162/05, of 4 July. Available from: http://base.garant.ru/70639826/

Chairman of Russia's Constitutional Court Valeriy Zorkin denounces Yeltsin's crimes. Available from: http://www.prezidentpress.ru/news/zakon/1622-glava-ks-rf-valeriyzorkin-protiv-prestupleniy-elcina.html

Constitution of the Russian Federation - 1993. Available from: http://base.garant. ru/10103000/7/\#block_7000

Federal Constitutional Law as of July 21, 1994, No. 1-FCL "On Constitutional Court of Russian Federation". Available from: http.//base.garant.ru/10101207/

Informative and Analytical Report on fulfillment of Russia's Constitutional Court decisions adopted during implementation of Constitutional Jurisprudence in 2015. Available from: http://www.ksrf.ru/ru/Info/Maintenance/Informationks/Pages/ReportKS201.aspx M

OAo Neftyanaya Kompaniya Yukosv. Russia. Application N 14902/04, Judgment of 24 June 2014. Available from: http://www.garant.ru/products/ipo/prime/doc/70059678/

Official Website of Russia's Constitutional Court. Available from: http://www.ksrf.ru/ru/info

ZoRKIN, V.D. Constitutional Justice in transitional stage of historical development of Russia. Available from: http://www.ksrf.ru/ru/News/Speech/Pages/ViewItem.aspx?ParamId=75

Zorkin, V. D. Problems of implementing Human Rights Convention. Available from: http:// www.ksrf.ru/ru/News/Speech/Pages/ViewItem.aspx?ParamId=72

Zorkin, V. D. The dialogue of the Constitutional Court of the Russian Federation and the European Court on Human Rights in the context of constitutional order. Available from: ksrf.ru>News/Speech/Pages/ViewItem.aspx 